\title{
Medicine \& Science in Sports \& Exercise
}

\section{Exercise to improve pediatric bone and fat: a systematic review and meta-analysis --Manuscript Draft--}

\begin{tabular}{|c|c|}
\hline Manuscript Number: & \\
\hline Full Title: & Exercise to improve pediatric bone and fat: a systematic review and meta-analysis \\
\hline Short Title: & Exercise, bone and fat in children \\
\hline Article Type: & Brief Review \\
\hline Keywords: & bone mineral density; lean mass; obesity; pediatric; physical activity. \\
\hline Corresponding Author: & $\begin{array}{l}\text { Belinda R. Beck, PhD,FACSM } \\
\text { Griffith University } \\
\text { Gold Coast campus, Queensland AUSTRALIA }\end{array}$ \\
\hline $\begin{array}{l}\text { Corresponding Author Secondary } \\
\text { Information: }\end{array}$ & \\
\hline Corresponding Author's Institution: & Griffith University \\
\hline $\begin{array}{l}\text { Corresponding Author's Secondary } \\
\text { Institution: }\end{array}$ & \\
\hline First Author: & Rossana Candiota Nogueira, MSc \\
\hline First Author Secondary Information: & \\
\hline Order of Authors: & Rossana Candiota Nogueira, MSc \\
\hline & Benjamin K. Weeks, PhD \\
\hline & Belinda R. Beck, PhD,FACSM \\
\hline Order of Authors Secondary Informe & \\
\hline Abstract: & $\begin{array}{l}\text { Purpose: To determine the effect of school-based, bone-focused exercise } \\
\text { interventions on bone, fat and lean mass in children by systematically reviewing and } \\
\text { meta-analyzing the literature. Methods: Potentially relevant papers were identified by } \\
\text { searching electronic databases. Abstracts were included if they described the effects } \\
\text { of an in-school exercise intervention for children } 5-17 \text { years old compared with } \\
\text { controls, and presented baseline and follow up results for bone, fat and lean measures } \\
\text { Identified studies were systematically reviewed for methodological quality. Meta- } \\
\text { analyses were performed for whole body (WB), lumbar spine (LS) and femoral neck } \\
\text { (FN) BMC (bone mineral content), fat and lean mass. Results: Sixteen eligible trials } \\
\text { were identified including eight RCTs, three CCTs and five non-randomized, non- } \\
\text { matched studies. The quality analysis revealed two studies had low, nine had medium } \\
\text { and five had a high risk of bias. Meta-analyses revealed a small positive effect of } \\
\text { bone-targeted exercise on WB BMC (standardized mean difference [SMD] of } 0.483 \text {, } \\
95 \% \mathrm{Cl} 0.132 \text { to } 0.833 \text { ), FN BMC (SMD=0.292, } 95 \% \mathrm{Cl}-0.022 \text { to } 0.607), \text { LS BMC (SMD } \\
=0.384,95 \% \mathrm{Cl} 0.193 \text { to } 0.575), \text { fat mass (SMD }=-0.248,95 \% \mathrm{Cl}-0.406 \text { to }-0.089 \text { ), and } \\
\text { lean mass (SMD= } 0.159,95 \% \mathrm{Cl}-0.076 \text { to } 0.394) \text {. Conclusion: A positive effect of } \\
\text { school-based, bone-targeted exercise was observed for bone, muscle and fat, but not } \\
\text { for lean mass. Excluding trials with high risk of bias strengthened that effect. } \\
\text { Considerable study heterogeneity may have obscured effects on lean mass. The } \\
\text { effects observed for bone and fat supports the pursuit of brief, jumping-focused } \\
\text { interventions to reduce fat as well as enhance musculoskeletal tissue in school age } \\
\text { children. }\end{array}$ \\
\hline
\end{tabular}


Exercise to improve pediatric bone and fat: a systematic review and meta-analysis

Rossana C. Nogueira, M.Sc. ${ }^{1,2}$, Benjamin K. Weeks, Ph.D. ${ }^{1,2}$ and Belinda Beck, Ph.D. ${ }^{1,2}$

Affiliations: ${ }^{1}$ Centre for Musculoskeletal Research, Griffith Health Institute, Gold Coast, Queensland, Australia

${ }^{2}$ School of Rehabilitation Sciences, Griffith University, Gold Coast, Queensland, Australia

Address correspondence to: AProf Belinda Beck, School of Rehabilitation Sciences, Griffith University Gold Coast campus, QLD 4222, Australia.

Email: b.beck@griffith.edu.au PH: +61 (07) 55528793 FAX: +61 (07) 55528674

Short title: Exercise, bone and fat in children

Key words: bone mineral density; lean mass; obesity; pediatric; physical activity.

Conflict of interest: The authors have no conflicts of interest to disclose.

Financial Disclosure: The authors have no financial relationships relevant to this article to disclose. 


\section{ABSTRACT}

Purpose: To determine the effect of school-based, bone-focused exercise interventions on bone, fat and lean mass in children by systematically reviewing and meta-analyzing the literature. Methods: Potentially relevant papers were identified by searching electronic databases. Abstracts were included if they described the effects of an inschool exercise intervention for children 5-17 years old compared with controls, and presented baseline and follow up results for bone, fat and lean measures. Identified studies were systematically reviewed for methodological quality. Meta-analyses were performed for whole body (WB), lumbar spine (LS) and femoral neck (FN) BMC (bone mineral content), fat and lean mass. Results: Sixteen eligible trials were identified including eight RCTs, three CCTs and five non-randomized, non-matched studies. The quality analysis revealed two studies had low, nine had medium and five had a high risk of bias. Meta-analyses revealed a small positive effect of bone-targeted exercise on WB BMC (standardized mean difference [SMD] of $0.483,95 \% \mathrm{CI} 0.132$ to 0.833 ), FN BMC $(\mathrm{SMD}=0.292,95 \% \mathrm{CI}-0.022$ to 0.607$), \mathrm{LS} \mathrm{BMC}(\mathrm{SMD}=0.384,95 \% \mathrm{CI} 0.193$ to $0.575)$, fat mass $(\mathrm{SMD}=-0.248,95 \% \mathrm{CI}-0.406$ to -0.089$)$, and lean mass $(\mathrm{SMD}=0.159$, 95\% CI -0.076 to 0.394). Conclusion: A positive effect of school-based, bone-targeted exercise was observed for bone, muscle and fat, but not for lean mass. Excluding trials with high risk of bias strengthened that effect. Considerable study heterogeneity may have obscured effects on lean mass. The effects observed for bone and fat supports the pursuit of brief, jumping-focused interventions to reduce fat as well as enhance musculoskeletal tissue in school age children. 


\section{BACKGROUND}

Paragraph number 1 A lack of physical activity and appropriate nutrition in youth is associated with the development of obesity and lifetime chronic disease $(2,40)$. It is estimated that $35 \%$ of the global population is overweight - a proportion that is growing, particularly among children (1). Overweight and obesity during childhood is a significant predictor of obesity in adulthood $(6,9,17,28,46,50)$. More than $10 \%$ of the world's school-aged children are overweight, signaling a burgeoning public health problem $(21,39)$. Both developed and developing countries have increased prevalence, with up to $30 \%$ of children overweight in the United States, China, United Kingdom and Australia $(10,41)$. Physical inactivity is also associated with deleterious effects on lean body mass elements, including bone and muscle. In 2000, there were 9 million osteoporotic fractures globally (18) and the incidence continues to rise due to an aging population. While osteoporosis is a condition that typically occurs in the elderly, physical activity during childhood provides a critical stimulus to the growing musculoskeletal system that may prevent osteoporotic fracture in old age $(31,44,51$, $53)$.

Paragraph number 2 It is well known that physical activity is an effective method of reducing overweight, optimizing cardiovascular, musculoskeletal and metabolic health and preventing chronic diseases $(38,47)$. It is also well recognized that the US National Health Survey physical activity recommendations are rarely met (2), and that physical inactivity persists into adulthood (46). The challenge of reaching daily physical activity targets is increased by differences in the nature, intensity and duration of exercises recommended for different tissues or systems. For example, non-weight bearing aerobic exercise that may be effective for fat loss will not adequately stimulate the 
skeleton to promote gains in bone. Performing multiple workouts for different body systems is highly impractical and decreases the likelihood that exercise recommendations will be met. In fact, it would be of great practical utility to determine if physical activity interventions that are known to enhance bone, also reduce fat. Some physical activity interventions have provided such evidence $(48,54)$ however, those data are rarely reported together.

Paragraph number 3 Thus, the aim of the current work is to systematically review the findings of school-based physical activity interventions that were designed to improve bone health, to determine if improvements in muscle and reductions in fat were also observed. A finding that broader health benefits for body composition can be obtained from bone-focused workouts for school-aged children will inform recommendations for pediatric exercise interventions.

\section{METHODS}

\section{Eligibility criteria}

Paragraph number 4 Comprehensive database searches were conducted in the first instance for predefined keywords: (1) ‘children', 'adolescents', 'kids', 'paediatrics', 'pediatrics' (yielded 2,408,264 studies); (2) 'exercise', 'physical activity', 'fitness', ‘energy expenditure' (yielded 707,741 studies); (3) 'obesity', 'obese', 'overweight', 'body fat', 'body weight' (yielded 658,708 studies); and (4) 'bone', 'bone mass', 'bone density', 'bone strength' (yielded 1,309,830 studies). As a second step, the four categories were combined to obtain studies including all of the search terms. Finally, all of the potential studies were manually analyzed for inclusion. The following search criteria were additionally applied: Humans, Male, Female, Meta-Analysis, Randomized 
Controlled Trial, Review, Journal Article, English, Portuguese, and Child: 0-18 years. In an attempt to acquire all relevant literature, the search was conducted in twelve databases: Medline (OvidSP), Pubmed (NLM), CINAHL (EBSCO), Cochrane Central Register of Controlled Trials (CENTRAL), Embase (OvidSP), PreMedline (OvidSP), ProQuest, PsycInfo (OvidSP), SPORTDiscuss (EBSCO), LILACS (Latin American and Caribbean Health Sciences), Web of Science and PEDro, up to August 2012. Finally, reference lists of relevant papers were hand-searched.

\section{Selection of the studies}

Paragraph number 5 The studies were defined as eligible if they described controlled, but not necessarily randomized, school-based physical activity interventions for healthy children between 5 to 17 years of age, inclusive. The trials must have implemented at least one type of exercise intervention, included baseline and follow up testing, and reported outcomes for bone and fat mass. The control group must have continued with normal physical education classes, according to the school curriculum. Identified papers and abstracts were screened and assessed for methodological quality based on titles and abstract. If eligibility was uncertain, the full text was consulted. A PRISMA flow diagram summarizing the process of identification, screening and eligibility of papers is presented in Figure 1 (36).

(figure 1 - diagram)

\section{Data collection, analysis and quality assessment}

Paragraph number 6 A single reviewer $(\mathrm{RN})$ assessed and screened all manuscripts. In cases of uncertainty, a second reviewer was consulted. After duplicate papers were removed from the search, remaining abstracts of each study were re-reviewed to verify content. Data extraction was performed by a single reviewer (RN). Data extracted 
included population, age, baseline characteristics, intervention activities and outcome measures.

Paragraph number 7 Studies were ranked by quality according to degree of bias risk. Since it is not possible to blind exercise intervention trials, it was not applied as a criterion of validity. The grading system, based on a previously published system (16), is presented in Table 1. The highest possible quality grade was 21 . For the purpose of the current review, a grade of 19-21 indicated low risk of bias; 16-18 indicated moderate risk; and a grade of 15 or below indicated high risk of bias.

\section{Meta-analysis}

Paragraph number 8 After systematically reviewing for study quality, a meta-analysis was conducted to quantify outcomes of the review. Meta-analyses were performed for whole body (WB), lumbar spine (LS) and femoral neck (FN) bone mineral content (BMC), lean and fat mass. Investigators for one study reported data for boys and girls independently, so those data were included in the meta-analysis separately. Not all studies that were systematically reviewed were included in the meta-analysis, as some did not present means and/or standard deviations for cases and controls or change in outcome measures. One trial only presented data graphically. Meta-analyses were initially performed including only trials with low to medium risk of bias, in order to draw conclusions from the most valid data. Data were then re-analyzed including the high risk of bias trials to determine if trial quality influenced outcomes.

Paragraph number 9 Meta-analyses were carried out with Meta-Analyst Beta software version 3.13 (Tufts Evidence-based Practice Center, US) (52). A random effects model was adopted. Study heterogeneity was examined using $\mathrm{I}^{2}$ as a measure of consistency, representing the percentage of total variation across studies for each meta-analysis. A 
value of $0 \%$ indicates no observed heterogeneity, and larger values show increasing heterogeneity (14). Effect size was represented by the standardized mean difference (SMD) along with 95\% confidence intervals. The convention of Cohen (7) was used for describing the strength of the effect size, based on Cohen's d. That is, 0.20 is a small effect, 0.50 a medium effect, and 0.80 is a large effect (14). Meta-regressions were not undertaken owing to low study numbers (15).

\section{RESULTS}

\section{Search results}

Paragraph number 10 A total of 1,067 papers were identified. After screening, 235 potential papers remained (Figure 1). Few papers reported both bone and fat outcome measures, thus only twenty relevant papers could ultimately be included in the systematic review $(3,5,11,12,19,22,25-27,32-34,37,45,48,49,54-56)$. Notably, some authors reported the same study in multiple publications; typically reporting different intervention intervals $(19,48)$, or study cohorts $(3,12,25,27,55,56)$. Of the twenty potentially-relevant trials, four were excluded $(26,48,55,56)$ because their data had been previously published in five other papers identified in our search $(12,19,25$, 27, 32). Therefore, the current review was based on the analysis of sixteen trials. Reviewed trials were conducted by American, Australian, Belgian, British, Canadian, Swedish and Swiss research groups.

\section{Study characteristics}

Paragraph number 11 The studies were heterogeneous in terms of study design, quality, target population, and outcome measures. An overview of the design, 
execution and outcomes of each study is presented in Table 2. Of the sixteen studies, eight were randomized controlled trials (RCT) $(11,12,22,25,27,33,49,54)$, three were clinical controlled trials $(\mathrm{CCT})(19,20,32)$ and the remaining five were neither randomized nor well-matched $(3,5,34,37,45)$. The type, duration and frequency of each exercise program varied widely, as did the intervention period, which ranged from nine weeks to three years. The frequency of exercise bouts varied from two to five days a week, including one protocol that divided physical activity (PA) into three daily sessions, five days a week (32). The physical activity programs of eight studies were composed primarily of jumping activities $(5,11,25,27,32,33,49,54)$, while others included aerobic exercise $(3,12,20,22,34,37,45,48)$, stretching $(3,12)$, or strength training (45).

\section{Quality assessment}

Paragraph number 12 Papers were grouped according to their quality ranking (table 2). Trial quality rankings ranged from 12-20, from highest to lowest risk of bias, respectively. Most of the trials were considered to have a moderate or high risk of bias, based on a lack of randomization $(5,19,20,32,34,37,45,49)$; lack of or low study compliance $(3,12,22,25,27,49)$ and intervention compliance $(3,4,12,25,32,33)$; lack of GRF data $(3,5,12,19,20,33,34,37,45,49,54)$; or a specific intervention program; short intervention period $(5,34)$; small sample size $(5,34)$ and lack of control of variables, such as physical activity history and/or calcium consumption $(3,5,12,19$, $20,22,25,27,34,49)$.

\section{Outcome measures}

Paragraph number 13 Results are presented as the difference in percent change between intervention and control groups, including the $P$ value for between-group 
differences if provided by the authors. Bone outcomes were primarily bone mineral content (BMC), bone mineral density (BMD) and volumetric BMD. Some trials also included bone area (BA). Lean and fat tissue outcomes included absolute fat mass (FM), absolute lean mass (LM), or fat free soft tissue (FFST). Some studies also provided percent body fat $(\% \mathrm{BF})$. Several papers calculated BMI so, despite the recognized limitations of the index $(8,30)$, BMI was also included. BMC, BMD, lean and fat mass were assessed using dual-energy x-ray absorptiometry (DXA) in all studies reporting those parameters. In addition, some trials evaluated percent body fat using caliper-based anthropometry $(11,34,49)$. Some investigators also examined indices of bone quality using quantitative ultrasound (QUS), measuring speed of sound (SOS), broadband ultrasound attenuation (BUA) and stiffness index (SI). Magnetic resonance imaging was used to analyze bone marrow adipose tissue volume and total body composition in two studies $(3,5)$.

(Table 1. Criteria and grading)

\section{Exercise interventions}

Paragraph number 14 The trials included in the review were designed to primarily examine the effects of high impact weight bearing exercise on bone; however, some tested the effect of multiple exercise modes. Six of the sixteen trials employed jump activities only, lasting an average of ten minutes $(11,25,27,32,33,54)$. One trial added a 5-minute warm-up and a 5-minute cool down to a 20-minute jumping regime (5). One 10-minute intervention was primarily composed of jumps, but also included two non-impact exercises (49). The remaining eight studies combined different types of exercise, such as strength training, aerobic training, stretching, skills development and 
high impact maneuvers for 30 to 80 minutes, two to five times per week $(3,12,19,20$, $22,34,37,45)$. Control groups were generally asked to continue usual physical education classes. Some protocols implemented stretching activities for those students not involved in the exercise intervention $(11,54)$.

\section{Sample characteristics}

Paragraph number 15 Sample sizes ranged from 20 to 447. All but two trials $(5,12)$, evaluated maturity using Tanner staging, age of peak high velocity (APHV), or bone age. The latter two methods are less common, but considered to be more valid for determining biological maturity than Tanner assessment (29, 35). According to participant age and/or Tanner classification, ten trials were conducted in prepubertal children $(5,11,12,19,20,22,27,33,37,49)$ or early pubertal children $(3)$, three in prepubertal and early pubertal children $(25,32,34)$ and two in peripubertal children $(45$, 54). The mean age of participants at baseline varied from six to fifteen years. The trials included black, white, Caucasian, and Asian boys and girls. Of the sixteen studies analyzed, eight were conducted in both sexes $(5,11,12,22,32-34,54)$, while two were conducted with boys only $(20,27)$.

\section{Exercise effects on bone, fat and lean mass}

Paragraph number 16 Fourteen of sixteen trials reported at least one positive effect from exercise on bone mass in children and adolescents. Between-group effects varied from $1.1 \%(3)$ to $10.3 \%(37,54)$. The results for fat and lean mass were more varied. Some trials reported gains in lean mass $(12,27,37)$, reductions in fat mass accumulation (3), or both, in the exercise compared to control group $(34,37,54)$. Nevertheless, some exercise interventions did not induce any significant difference in 
modification of body composition between groups $(5,11,19,20,22,25,32,33,45,49)$.

Trials will be discussed in order of quality, from least to most risk of bias.

\section{Low risk of bias trials}

Paragraph number 17 The highest scoring trial, with a quality score (QS) of 20 (reflecting the lowest risk of bias) was conducted by Fuchs et al. (11). Their weightbearing intervention was conducted with prepubertal children over seven months. They observed 4.9\% greater improvements in FN BMC, 2.3\% more FN area, 3.6\% more LS BMC, and 2\% more aBMD in the intervention group than control. No differences were observed between groups in terms of change in lean or fat mass.

Paragraph number 18 The second strongest trial, an 8-month jumping regime for adolescents, was conducted by Weeks and colleagues (54), with a QS of 19. Whole body, FN and TR BMC of the intervention group improved 3.6\%, 6.0\% and 10.3\% more than the control group, respectively. Intervention boys gained more lean mass $(2.3 \%)$ and lost more fat $(-3.5 \%)$ than controls.

\section{Moderate risk of bias trials}

Paragraph number 19 MacDonald and others (22) (QS 18), conducted an 11-month weight-bearing intervention for prepubertal boys and girls. Intervention group boys increased WB BMC and LS BMC 2.1\% and 2.9\% more than control, respectively. However, there were no between groups differences in change in fat and lean mass for boys or girls. MacKelvie et al. (27) conducted a 20-month exercise intervention for prepubertal boys (QS 17) and girls (25) (QS 16), but reported the findings separately. Intervention group boys increased FN BMC $4.5 \%$ and lean mass $4.2 \%$ more than the control group; while intervention group girls increased LS BMC 3.7\% and FN BMC 
$4.6 \%$ more than controls. Neither fat nor lean mass change was different between groups for girls.

Paragraph number 20 MacKay and colleagues (QS 17) implemented a similar trial of weight-bearing exercises for prepubertal children over eight months (33). Trochanteric aBMD $(1.2 \%)$ increased more in the intervention group than control; however no other outcome measure reached significance, including fat and lean mass. The study posed moderate risk of bias due to low study compliance and absence of supporting data (e.g. physical activity and calcium intake).

Paragraph number 21 In contrast to the studies employing targeted weight-bearing interventions, Linden et al. (19) (QS 17) examined the effect of four additional 40minute moderate-to-vigorous physical activity classes per week, versus one standard 60minute PE class, for two years. The intervention group increased WB aBMD 1.5\%; LS aBMD 1.6\%; LS BMC 7\%; and lean mass 3.8\% more than controls, but also increased fat mass $9.5 \%$ more than controls. The authors reported results only for girls, but conducted an identical program with boys (20), presenting results after one year (QS 16). In that study, intervention boys gained $6.1 \%, 2.1 \%$ and $2.4 \%$ more BMC, aBMD and width at L3 than controls. There were no differences in change in lean or fat mass between groups.

Paragraph number 22 Schneider and colleagues (45) (QS 17) examined the effect of an eight month aerobic and strength training protocol plus $500 \mathrm{mg}$ /day of calcium for adolescents, repeated annually for three years. They observed a $4.9 \%$ greater increase in thoracic spine BMC in the exercise group than control but no difference in change in any other bone parameter, fat or lean mass. The latter studies $(19,20,45)$ had some 
limitations, such as lack of randomization, non-specific intervention activities and no GRFs reported, and were therefore considered at moderate risk of bias.

Paragraph number 23 Morris and co-workers (37) conducted a 10-month exercise intervention for prepubertal girls, comprising general activities and weight-bearing training (QS 16). The intervention group exhibited 5.5\%, 5.5\%, and 4.5\% greater increases in WB, LS and FN BMC than controls, respectively, along with 3.4\% greater gains in lean mass and $6.2 \%$ less gain in fat. The study was assigned a quality score of 16 due to a lack of randomization, non-specific intervention activities, and the absence of GRF data.

Paragraph number 24 In a study of twin prepubertal girls, Van Langendonck and colleagues (49) examined the effect of a nine-month, bone-specific training regime followed by some non-impact movements. Greater increases were observed in femoral neck aBMD (1.6\%) and proximal femur BMC (2.4\%) and aBMD (1.4\%) in the intervention group than controls. Fat mass increased $3.8 \%$ and lean mass $0.7 \%$ in the intervention group more than in controls; also, intervention participants reduced percent fat $2.1 \%$ more than controls. The study was assigned moderate risk of bias (QS 16) due to a lack of GRF data, maturity level (although measured, not presented) and randomization.

\section{High risk of bias trials}

Paragraph number 25 McKay et al. (32) implemented an eight month translational frequent jumping trial for pre-pubertal children. The intervention group increased trochanteric $\mathrm{BMC} 2.7 \%$ and bone area $2.0 \%$, and proximal femur $\mathrm{BMC} 2.0 \%$ and area $1.3 \%$ more than controls, however the control group increased WB BMC $1.3 \%$ more than the intervention group. There were no between group differences in change in lean 
and fat mass. Those findings are considered to be at high risk of bias (QS 15) due to the lack of randomization and low compliance in the intervention group. The tendency for higher physical activity in the intervention than control group at baseline may also have confounded results.

Paragraph number 26 Only one study did not report any positive results for BMC, BMD or bone area (5). The aim of that pilot trial was to determine the effect of a tenweek bone-specific exercise intervention on bone marrow adipose tissue in prepubertal children. While significant changes in bone measures were not observed, a significant decrease in bone marrow adipose tissue was reported. The study, however, was considered at high risk of bias with QS of 14 due to very small sample size, lack of randomization and GRF data and short duration.

Paragraph number 27 One research group incorporated general physical activities into school time for pre and early pubertal children and reported different group findings in two papers (both QS 13). One of the studies included boys and girls (12), and the other, only black girls (3). In both cases, intervention groups increased WB BMD 3.6\% (12) and $1.1 \%$ (3) more than control groups. Greater fat gain was observed in the control group than the intervention group, with an increase in percent fat for controls only (3). Although both trials were randomized, there was low engagement (study compliance) and low protocol compliance and confounding variables were not controlled, resulting in high risk of bias.

Paragraph number 28 McWhannel et al. (34) reported the effects of a 9-week highimpact vigorous activity intervention for pre and early pubertal children, compared with a control group and a lifestyle activities group. The intervention group increased WB BMC 5.8\% and BMD 1.5\% more than controls. No significant differences were found 
between the lifestyle group and either the control or intervention groups. There were no between group differences in fat change. The trial was graded at very high risk of bias (QS 12) due to the lack of control for confounding variables, inadequate intervention period, small sample size, and lack of randomization.

\section{Meta-analysis}

Paragraph number 29 Forest plots illustrate the results of the random-effects metaanalyses (Figure 2-4). Including only the seven trials with low and medium risk of bias $(19,20,25,27,37,49,54)$, a small effect of exercise on WB BMC was observed (SMD $=0.483,95 \%$ CI 0.132 to $\left.0.833, \mathrm{I}^{2}=0.76\right)$. Including the two high risk of bias trials in the secondary meta-analysis $(32,34)$, the observed effect remained small, and standardized mean difference was lower $\left(\mathrm{SMD}=0.393,95 \%\right.$ CI 0.043 to $0.744, \mathrm{I}^{2}$ $=0.81)$.

Paragraph number 30 A small effect (SMD $=0.292,95 \%$ CI -0.022 to $0.607, \mathrm{I}^{2}=0.62$ ) of exercise on FN BMC was revealed from meta-analysis of the low to medium risk of bias trials (the same trials included in the WB BMC meta-analysis). Again, inclusion of the high risk of bias trials weakened the effect $\left(\mathrm{SMD}=0.270,95 \% \mathrm{CI} 0.013\right.$ to $0.527, \mathrm{I}^{2}$ $=0.59$ ).

Paragraph number 31 A small effect of exercise on LS BMC was found from the six studies of low and medium risk of bias with available data $(\mathrm{SMD}=0.384,95 \% \mathrm{CI}$ 0.193 to $0.575, \mathrm{I}^{2}=0$ ). A smaller effect was observed when studies of high risk of bias were included $\left(\mathrm{SMD}=0.263,95 \%\right.$ CI 0.078 to $\left.0.447, \mathrm{I}^{2}=0.21\right)$. 
Paragraph number 32 From the ten low- and moderate-risk of bias studies including lean mass data, there was a very small effect of exercise on lean mass ( $\mathrm{SMD}=0.159$, $95 \% \mathrm{CI}-0.076$ to $\left.0.394, \mathrm{I}^{2}=0.70\right)$. When the other two high risk of bias studies were included, the effect was slightly lower $\left(\mathrm{SMD}=0.127,95 \% \mathrm{CI}-0.073\right.$ to $0.328, \mathrm{I}^{2}$ $=0.66$ ). The meta-analysis of fat mass from the nine low or medium risk trials with available data yielded a small effect of exercise $(\mathrm{SMD}=-0.248,95 \% \mathrm{CI}-0.406$ to $0.089, \mathrm{I}^{2}=0.33$ ), which was not markedly different from that observed when high risk of bias trials were included $\left(\mathrm{SMD}=-0.279,95 \% \mathrm{CI}-0.434\right.$ to $\left.-0.124, \mathrm{I}^{2}=0.43\right)$.

\section{DISCUSSION}

Paragraph number 33 The goal of the current work was to investigate the ability of a range of school-based interventions designed to improve bone health, to also reduce fat in children. Findings suggest that indeed the short bouts of high intensity weight bearing activity that can positively affect growing bone, can in some cases also improve lean and fat tissue. While our focus has been on interventions that may be appropriate for improving bone and reducing fat, we note that observations of simultaneous increases in lean mass are highly beneficial for both bone and fat metabolism. That is, increased muscle loading of the skeleton can stimulate bone adaptation (43), and increased muscle mass raises metabolism thereby assisting weight loss $(13,42)$.

Paragraph number 34 Body composition outcomes following in-school exercise interventions have been the subject of considerable research, however, the effects on bone, muscle and fat are typically reported under separate cover. Reviews of studies investigating the benefits of school-based physical activity similarly typically report bone and soft tissue outcomes separately $(13,16)$. 
Paragraph number 35 The trials included in the current systematic review represent a variety of predominantly bone-targeted exercise interventions, including jumping (11, $25,27,32,49,54)$, jumping and aerobic exercise (22), jumping and circuit training (33, 37), or general moderate-to-vigorous circuit training $(3,5,12,19,34)$. As not all trials reported ground reaction forces, it is not possible to quantify all reported loading regimes. However, it is well-recognized that the prevailing high impact loading activities utilized (such as jumping) are likely to be optimally osteogenic as a function of the high bone strain magnitudes and rates of loading they engender. Considerable differences in frequency, duration, and overall program length existed, which was reflected in the marked study heterogeneity observed in WB and lean meta-analyses. Nevertheless, the most effective interventions included short (10- to 12-minute) sessions of jumping exercises, executed two to three times per week $(25,27,54)$.

Paragraph number 36 In general, the trials that combined jumping activities with some other moderate-to-vigorous physical activity resulted in the greatest fat and lean mass changes, while the trials that were limited to jumping activities were more likely to report positive results for bone mass, but not for other body composition parameters. Increases in bone mass were found at the $\mathrm{WB}(19,22,25,34,37,54), \mathrm{FN}(11,20,22$, $25,27,34,37,49,54)$, and LS $(20,25,27,34,49,54)$. The effect on muscle was more variable with some positive findings $(3,12,27,37,54)$, but not all $(20,22,25,34,49)$. High study heterogeneity likely accounts for the inconsistent effects for lean mass. Most trials, however, observed a reduction or less gain of fat in intervention groups compared to controls $(19,20,22,25,27,34,37,49,54)$. Low study heterogeneity may have enhanced the ability to detect an effect for fat.

Paragraph number 37 The quality scoring scheme utilized to quantify bias in the included studies (16), was an important tool to identify limitations and confounding 
factors in trials of exercise for bone. Ultimately, the quality score performed the role of final screening for our meta-analyses and enhanced the validity of our findings by excluding data that are biased by weaknesses in methodology. There was considerable variation in trial quality with only two papers considered to be at low risk of bias, nine of moderate risk, and five considered to have a high risk of bias. Ultimately, excluding the trials with a high risk of bias only strengthened the findings of the meta-analyses suggesting that weaknesses in trial design may limit the ability to detect true exercise effects.

Paragraph number 38 Our findings that short bouts of bone-focused exercise can improve WB, FN and LS BMC in pediatric subjects, corroborates those of previous bone-specific reviews $(16,24)$. Although bone-specific programs presented a small effect in relation to each measurement, the effect was greater when the high risk of bias studies were excluded. Funnel plots for WB, LS and FN BMC did not exhibit asymmetry, suggesting no notable publication bias (data not shown). Notably, low study heterogeneity was observed for the LS, while moderate and high heterogeneity was observed for FN and WB, respectively. The less consistent treatment effects on the FN and WB might reflect the relatively wide variety of exercise types and doses included and the nature of site-specific osteogenic responses.

Paragraph number 39 Our observation that bone-targeted exercise programs may simultaneously reduce fat in pediatric groups is a fortuitous, if unintentional, outcome with positive implications for exercise prescription for children. While our lean mass observations were somewhat equivocal and, overall, indicative of only a weak effect of bone-targeted exercise programs, the considerable variation in outcomes between trials likely reflects the differing sensitivity of muscle to the heterogeneous exercise interventions, also reflected by high $\mathrm{I}^{2}$ values for lean mass. It is possible jump focused 
exercise programs do not contain a sufficient degree of progression to maximize muscle adaptation. Training progression is likely to be beneficial to both muscle and bone and should therefore be tested further.

\section{LIMITATIONS}

Paragraph number 40 Not all reviewed trials were included in the meta-analyses owing to an absence of numerical data (e.g. standard deviations of the change after intervention) $(3,5,11,12,23,45)$. While LS and fat mass meta-analyses exhibited low study heterogeneity, other meta-analyses exhibited moderate (i.e. FN BMC) or high (i.e. WB BMC and lean mass) study heterogeneity, limiting the generalizability of those findings. Meta-regressions to control study level covariates could not be performed due to the small number of trials (15).

\section{CONCLUSION}

Paragraph number 41 The benefits of jumping exercise for bone are well established, to the extent that it is recommended for the prevention of osteoporosis. The aim of the current systematic review was to determine if pediatric exercise interventions designed to improve bone also improve soft tissue elements of body composition that influence risk of other chronic diseases. We found that indeed bone-targeted exercise programs will improve $\mathrm{BMC}$ and reduce fat mass (or at least mitigate gain). The evidence for lean mass is less convincing. Although the optimal dose and type of exercise to improve bone, muscle and fat have yet to be established, findings provide optimism for efficiencies in exercise recommendations. 


\section{Acknowledgments:}

The results of the present study do not constitute endorsement by ACSM.

Funding Source: No external funding was secured for this study.

Conflict of interest: The authors have no conflicts of interest to disclose. 


\section{REFERENCES}

1. Alwan A. Global status report on noncommunicable diseases 2010. World Health Organization; 2011.

2. Andersen LB, Harro M, Sardinha LB et al. Physical activity and clustered cardiovascular risk in children: a cross-sectional study (The European Youth Heart Study). Lancet. 2006;368(9532):299-304.

3. Barbeau P, Johnson MH, Howe CA et al. Ten months of exercise improves general and visceral adiposity, bone, and fitness in black girls. Obesity. 2007;15(8):2077-85.

4. Boreham CAG, McKay HA. Physical activity in childhood and bone health. Brit $J$ Sport Med. 2011;45(11):877-9.

5. Casazza K, Hanks L, Hidalgo B, Hu H, Affuso O. Short-term physical activity intervention decreases femoral bone marrow adipose tissue in young children: A pilot study. Bone. 2012;50(1):23-7.

6. Clarke WR, Lauer RM. Does childhood obesity track into adulthood? Crit Rev Food Sci. 1993;33(4-5):423-30.

7. Cohen J. Statistical power analysis for the behavioral sciences. 2nd ed. Hillsdale, (NJ): Lawrence Erlbaum Associates; 1988, 567 p.

8. Cole TJ, Bellizzi MC, Flegal KM, Dietz WH. Establishing a standard definition for child overweight and obesity worldwide: international survey. Brit Med J. 2000;320(7244):1240.

9. Craigie AM, Lake AA, Kelly SA, Adamson AJ, Mathers JC. Tracking of obesityrelated behaviours from childhood to adulthood: A systematic review. Maturitas. 2011.

10. Flynn MAT, McNeil DA, Maloff B et al. Reducing obesity and related chronic disease risk in children and youth: a synthesis of evidence with 'best practice' recommendations. Obes Rev. 2006;7:7-66.

11. Fuchs RK, Bauer JJ, Snow CM. Jumping improves hip and lumbar spine bone mass in prepubescent children: a randomized controlled trial. $J$ Bone Miner Res. 2001;16(1):148-56.

12. Gutin B, Yin Z, Johnson M, Barbeau P. Preliminary findings of the effect of a 3-year after-school physical activity intervention on fitness and body fat: the Medical College of Georgia Fitkid Project. Int J Pediatr Obes. 2008;3 Suppl 1:3-9.

13. Harris KC, Kuramoto LK, Schulzer M, Retallack JE. Effect of school-based physical activity interventions on body mass index in children: A meta-analysis. Can Med Assoc J. 2009;180(7).

14. Higgins J, Thompson SG, Deeks JJ, Altman DG. Measuring inconsistency in metaanalyses. 2003;327(7414):557-60.

15. Higgins JP, Green S, Collaboration C. Cochrane handbook for systematic reviews of interventions. Wiley Online Library; 2008. 
16. Hind K, Burrows M. Weight-bearing exercise and bone mineral accrual in children and adolescents: A review of controlled trials. Bone. 2007;40(1):14-27.

17. James PT, Leach R, Kalamara E, Shayeghi M. The worldwide obesity epidemic. Obes Res. 2012;9(S4):228S-33S.

18. Johnell O, Kanis J. An estimate of the worldwide prevalence and disability associated with osteoporotic fractures. Osteoporosis Int 2006;17(12):1726-33.

19. Linden C, Ahlborg HG, Besjakov J, Gardsell P, Karlsson MK. A school curriculumbased exercise program increases bone mineral accrual and bone size in prepubertal girls: two-year data from the pediatric osteoporosis prevention (POP) study. $J$ Bone Miner Res. 2006;21(6):829-35.

20. Linden $\mathrm{C}$, Alwis $\mathrm{G}$, Ahlborg $\mathrm{H}$ et al. Exercise, bone mass and bone size in prepubertal boys: one-year data from the pediatric osteoporosis prevention study. Scand J Med Sci Spor. 2007;17(4):340-7.

21. Lobstein T, Baur L, Uauy R. Obesity in children and young people: a crisis in public health. Obes Rev. 2004;5(1):4-104.

22. Macdonald HM, Kontulainen S, Petit M, Beck T, Khan K, McKay H. Does a novel school-based physical activity model benefit femoral neck bone strength in pre- and early pubertal children? Osteoporosis Int. 2008;19(10):1445-56.

23. Macdonald HM, Kontulainen SA, Mackelvie-O'Brien KJ et al. Maturity- and sexrelated changes in tibial bone geometry, strength and bone-muscle strength indices during growth: a 20-month pQCT study. Bone. 2005;36(6):1003-11.

24. MacKelvie KJ, Khan KM, McKay HA. Is there a critical period for bone response to weight-bearing exercise in children and adolescents? A systematic review. Br J Sports Med. 2002;36(4):250-7.

25. MacKelvie KJ, Khan KM, Petit MA, Janssen PA, McKay HA. A school-based exercise intervention elicits substantial bone health benefits: a 2-year randomized controlled trial in girls. Pediatrics. 2003;112(6):e447-e52.

26. MacKelvie KJ, McKay HA, Petit MA, Moran O, Khan KM. Bone mineral response to a 7-month randomized controlled, school-based jumping intervention in 121 prepubertal boys: associations with ethnicity and body mass index. $J$ Bone Miner Res. 2002;17(5):834-44.

27. MacKelvie KJ, Petit MA, Khan KM, Beck TJ, McKay HA. Bone mass and structure are enhanced following a 2-year randomized controlled trial of exercise in prepubertal boys. Bone. 2004;34(4):755-64.

28. Magarey AM, Daniels LA, Boulton TJ, Cockington RA. Predicting obesity in early adulthood from childhood and parental obesity. Int J Obesity. 2003;27(4):505-13.

29. Mahmoodi S, Sharif BS, Chester EG, Owen JP, Lee R. Skeletal growth estimation using radiographic image processing and analysis. IEEE $T$ Inf Technol $B$. 2000;4(4):292-7.

30. Maynard LM, Wisemandle W, Roche AF, Chumlea WC, Guo SS, Siervogel RM. Childhood body composition in relation to body mass index. Pediatrics. 2001;107(2):344-50. 
31. McKay H, Smith E. Winning the Battle Against Childhood Physical Inactivity: The Key to Bone Strength? J Bone Miner Res. 2008;23(7):980-5.

32. McKay HA, MacLean L, Petit M et al. "Bounce at the Bell": a novel program of short bouts of exercise improves proximal femur bone mass in early pubertal children. $\mathrm{Br} \mathrm{J}$ Sports Med. 2005;39(8):521-6.

33. McKay HA, Petit MA, Schutz RW, Prior JC, Barr SI, Khan KM. Augmented trochanteric bone mineral density after modified physical education classes: A randomized school-based exercise intervention study in prepubescent and early pubescent children. J Pediatr. 2000;- 136(- 2):- 162.

34. McWhannell N, Henaghan JL, Foweather L et al. The effect of a 9-week physical activity programme on bone and body composition of children aged 10-11 years: an exploratory trial. Int J Sports Med. 2008;29(12):941-7.

35. Mirwald RL, Baxter-Jones ADG, Bailey DA, Beunen GP. An assessment of maturity from anthropometric measurements. Med Sci Sports Exerc. 2002;34(4):689.

36. Moher D, Liberati A, Tetzlaff J, Altman DG. Preferred reporting items for systematic reviews and meta-analyses: the PRISMA statement. Int J Surg. 2010;8(5):336.

37. Morris FL, Naughton GA, Gibbs JL, Carlson JS, Wark JD. Prospective ten-month exercise intervention in premenarcheal girls: positive effects on bone and lean mass. $J$ Bone Miner Res. 1997;12(9):1453-62.

38. Mountjoy $\mathrm{M}$, Andersen LB, Armstrong $\mathrm{N}$ et al. International Olympic Committee consensus statement on the health and fitness of young people through physical activity and sport. Brit J Sport Med. 2011;45(11):839-48.

39. Ogden CL, Carroll MD, Curtin LR, Lamb MM, Flegal KM. Prevalence of High Body Mass Index in US Children and Adolescents, 2007-2008. J Am Med Assoc. 2010;303(3):242-9.

40. Pekkinen M, Viljakainen H, Saarnio E, Lamberg-Allardt C, Mäkitie O. Vitamin D Is a Major Determinant of Bone Mineral Density at School Age. PloS one. 2012;7(7):e40090.

41. Popkin BM. Recent dynamics suggest selected countries catching up to US obesity. Am J Clin Nutr. 2010;91.

42. Pratley R, Nicklas B, Rubin $M$ et al. Strength training increases resting metabolic rate and norepinephrine levels in healthy 50-to 65-yr-old men. J Appl Physiol. 1994;76(1):133-7.

43. Rubin CT, Lanyon L. Regulation of bone formation by applied dynamic loads. $J$ Bone Joint Surg Am. 1984;66(3):397-402.

44. Scerpella T, Dowthwaite J, Rosenbaum P. Sustained skeletal benefit from childhood mechanical loading. Osteoporosis Int. 2011;22(7):2205-10.

45. Schneider M, Dunton GF, Bassin S, Graham DJ, Eliakim AF, Cooper DM. Impact of a school-based physical activity intervention on fitness and bone in adolescent females. $J$ Phys Act Health. 2007;4(1):17-29. 
46. Telama R, Yang X, Viikari J, Välimäki I, Wanne O, Raitakari O. Physical activity from childhood to adulthood: a 21-year tracking study. Am J Prev Med. 2005;28(3):267-73.

47. Tobias JH, Steer CD, Mattocks CG, Riddoch C, Ness AR. Habitual Levels of Physical Activity Influence Bone Mass in 11-Year-Old Children From the United Kingdom: Findings From a Large Population-Based Cohort. J Bone Miner Res. 2006;22(1):101-9.

48. Valdimarsson O, Linden C, Johnell O, Gardsell P, Karlsson MK. Daily physical education in the school curriculum in prepubertal girls during 1 year is followed by an increase in bone mineral accrual and bone width--data from the prospective controlled Malmo pediatric osteoporosis prevention study. Calcified Tissue Int. 2006;78(2):65-71.

49. Van Langendonck L, Claessens A, Vlietinck R, Derom C, Beunen G. Influence of weight-bearing exercises on bone acquisition in prepubertal monozygotic female twins: a randomized controlled prospective study. Calcified Tissue Int. 2003;72(6):666-74.

50. Venn AJ, Thomson RJ, Schmidt MD et al. Overweight and obesity from childhood to adulthood: a follow-up of participants in the 1985 Australian Schools Health and Fitness Survey. Med J Australia. 2007;186(9):458.

51. Vicente-Rodríguez G. How does exercise affect bone development during growth? Sports med. 2006;36(7):561-9.

52. Wallace BC, Schmid CH, Lau J, Trikalinos TA. Meta-Analyst: software for metaanalysis of binary, continuous and diagnostic data. BMC Med Res Methodol. 2009;9(1):80.

53. Weeks BK, Beck BR. The Relationship between Physical Activity and Bone during Adolescence Differs according to Sex and Biological Maturity. J Osteoporos. 2010;2010:1-9.

54. Weeks BK, Young CM, Beck BR. Eight months of regular in-school jumping improves indices of bone strength in adolescent boys and Girls: the POWER PE study. J Bone Miner Res. 2008;23(7):1002-11.

55. Yin Z, Gutin B, Johnson MH et al. An environmental approach to obesity prevention in children: Medical College of Georgia FitKid Project year 1 results. Obes Res. 2005;13(12):2153-61.

56. Yin Z, Moore JB, Johnson MH et al. The Medical College of Georgia Fitkid project: the relations between program attendance and changes in outcomes in year 1. Int J Obes. 2005;29 Suppl 2:S40-5. 
Figure 1. PRISMA flow diagram of the search process of exercise trials with bone, fat and lean mass outcomes

Figure 2. Forest plot for meta-analysis of the effect of exercise on WB BMC in children.

Figure 3. Forest plot for meta-analysis of the effect of exercise on A) FN BMC and B) LS BMC in children.

Figure 4. Forest plot for meta-analysis of the effect of exercise on A) WB fat mass and B) WB lean mass in children. 
Table 1. Criteria used for the quality assessment of the trials in the systematic review (14).

\begin{tabular}{|c|c|c|}
\hline Criteria & Grade & Description \\
\hline \multirow[t]{3}{*}{ Randomisation } & 1 & $\begin{array}{l}\text { Groups were not randomised and the presence of } \\
\text { discrepancies in baseline characteristics }\end{array}$ \\
\hline & 2 & Groups were not randomised but were well-matched \\
\hline & 3 & Groups were randomised \\
\hline \multirow{3}{*}{$\begin{array}{l}\text { Compliance to the } \\
\text { study }\end{array}$} & 1 & Losses were greater than $30 \%$ or not reported \\
\hline & 2 & Losses were between 21 and $30 \%$ \\
\hline & 3 & Losses were $20 \%$ or less \\
\hline \multirow{3}{*}{$\begin{array}{l}\text { Compliance to the } \\
\text { exercise intervention }\end{array}$} & 1 & Less than $70 \%$ or not reported \\
\hline & 2 & Between 71 and $80 \%$ \\
\hline & 3 & $81 \%$ or greater \\
\hline \multirow[t]{3}{*}{ Exercise intervention } & 1 & $\begin{array}{l}\text { No specific intervention: general physical activities and } \\
\text { choices were given to participants and no measure of GRF }\end{array}$ \\
\hline & 2 & Specific intervention but no measure of GRF \\
\hline & 3 & Specific intervention and measurement of GRF \\
\hline \multirow[t]{3}{*}{ Confounding variables ${ }^{\dagger}$} & 1 & Lack of control for confounding variables ( $\leq 3$ variables) \\
\hline & 2 & Control over some confounding variables (4-7 variables) \\
\hline & 3 & Control over most confounding variables ( $8+$ variables) \\
\hline \multirow[t]{3}{*}{ Duration of trial } & 1 & Less than 6 months \\
\hline & 2 & $6-12$ months \\
\hline & 3 & Greater than 12 months \\
\hline \multirow[t]{3}{*}{ Sample size } & 1 & Less than 20 per group \\
\hline & 2 & $20-40$ per group \\
\hline & 3 & +40 per group \\
\hline
\end{tabular}

$\uparrow$ variables include: (maturity status - peak height velocity or Tanner stage; age; height, weight; baseline physical activity and calcium intake; exercise history; calcium history; extraphysical exercise and calcium intake during trial).

GRF, ground reaction force 
Table 2. Trial characteristics and quality grades for the effect of exercise on bone, fat and lean mass in children

\begin{tabular}{|c|c|c|c|c|c|c|c|}
\hline Author & Participants & Design & Intervention & Measures & Results & Limitations & Grade \\
\hline $\begin{array}{l}\text { Fuchs, et al. } \\
2001 \text { (11) }\end{array}$ & $\begin{array}{l}\text { Boys and girls } \\
\text { White and Asian } \\
\text { EX: } 45 \text { CO: } 44 \\
7.6 \pm 0.2 \text { years }\end{array}$ & $\begin{array}{l}\text { Randomised } \\
90 \% \text { study compliance } \\
\text { PA and Ca considered } \\
\text { Tanner to assess } \\
\text { maturity } \\
\text { United States }\end{array}$ & $\begin{array}{l}7 \text { months } \\
\text { EX: } 3 \text { times per week } \\
20 \mathrm{~min}: 5 \mathrm{~min} \text { warm-up }-10 \mathrm{~min} \\
50-100 \text { jumps off } 61 \mathrm{~cm} \text { boxes } \\
\text { Additional to PE } \\
\text { CO: stretching instead of jumps } \\
\text { GRF= up to } 8.8 \text { times body weight } \\
96 \% \text { intervention compliance }\end{array}$ & $\begin{array}{l}\text { FN BMC } \\
\text { FN BMD } \\
\text { FN BA } \\
\text { LS BMC } \\
\text { LS BMD } \\
\text { LS BA } \\
\% \text { BF }\end{array}$ & $\begin{array}{l}+4.9 \%, \mathrm{p}<0.001 \\
\text { NS ( } \mathrm{p} \text { value not reported }) \\
+2.3 \% P<0.001 \\
+3.6 \%, P<0.05 \\
+2.0 \%, P<0.01 \\
\text { NS, } P>0.05 \\
\text { NS }(P \text { value not reported) }\end{array}$ & $\begin{array}{l}\text { Did not present lean mass or } \\
\text { fat mass from DXA testing. } \\
\text { APHV not reported }\end{array}$ & 20 \\
\hline $\begin{array}{l}\text { Weeks, et al. } \\
2008 \text { (52) }\end{array}$ & $\begin{array}{l}\text { Boys and girls } \\
\text { Ethnicity not reported } \\
\text { EX: } 43 \text { CON: } 38 \\
13.8 \pm 0.4 \text { years }\end{array}$ & $\begin{array}{l}\text { Randomised } \\
\text { PA and Ca considered } \\
82 \% \text { study compliance } \\
\text { Tanner and APHV to } \\
\text { assess maturity } \\
\text { Australia }\end{array}$ & $\begin{array}{l}8 \text { months } \\
10 \text { min jumping activity } \\
\text { EX: } 2 \text { times per week } \\
(\sim 300 \text { jumps }) \\
80 \% \text { intervention compliance } \\
\text { Additional to PE } \\
\text { CO: stretching instead of jumps } \\
80 \% \text { intervention compliance } \\
\text { GRF calculated but not presented }\end{array}$ & $\begin{array}{l}\text { WB BMC } \\
\text { FN BMC } \\
\text { FN BMD, BA } \\
\text { LS BMC, BMD, BA } \\
\text { TR BMC } \\
\text { FM } \\
\text { LM }\end{array}$ & $\begin{array}{l}+3.6 \%, P=0.001 \\
+6 \%, P=0.03 \\
\text { NS }(P \text { value not reported }) \\
\text { NS }(P \text { value not reported }) \\
+10.3 \%, P=0.001 \\
\text { NS }(P \text { value not reported }) \\
+2,3 \%, P=0.001\end{array}$ & GRF not reported & 19 \\
\hline $\begin{array}{l}\text { MacDonald, et } \\
\text { al. } 2008(20)\end{array}$ & $\begin{array}{l}\text { Boys and girls } \\
\text { Caucasian and Asian } \\
\text { EX: } 293 \text { CO: } 117 \\
9-11 \text { years }\end{array}$ & $\begin{array}{l}\text { Randomised } \\
42 \% \text { study compliance } \\
\text { Tanner and APHV to } \\
\text { assess maturity } \\
\text { Canada }\end{array}$ & $\begin{array}{l}11 \text { months } \\
\text { EX: } 5 \text { times per week } \\
15 \text { min: skipping } \& \text { aerobic } \\
\text { activities }+30 \text { counter movement } \\
\text { jumps/day ( } 3 \times 10 / \text { day) } \\
\text { Additional to PE } \\
\text { GRF: } 5 \text { times body weight for } \\
\text { jumps and } 1-3 \text { times for running } \\
\text { and skipping (previous reports) } \\
82 \% \text { intervention compliance }\end{array}$ & $\begin{array}{l}\text { WB BMC } \\
\text { LS BMC } \\
\text { FN BMC } \\
\text { PF BMC } \\
\text { FM } \\
\text { LM }\end{array}$ & $\begin{array}{l}+2.1 \% P=0.03 \text { boys; NS girls } \\
+2.9 \%, P=0.05 \text { boys; NS girls } \\
\text { NS } P=0.78 \text { boys; NS } P=0.16 \text { girls } \\
\text { NS for boys and girls } \\
\text { NS for boys and girls } \\
\text { NS for boys and girls }\end{array}$ & $\begin{array}{l}\text { Study compliance } \\
\text { PA and Ca not reported }\end{array}$ & 18 \\
\hline $\begin{array}{l}\text { Schneider, et } \\
\text { al. } 2007 \text { (43) }\end{array}$ & $\begin{array}{l}\text { Girls } \\
\text { Caucasian, Asian, } \\
\text { African } \\
\text { EX: } 63 \text { CO: } 59 \\
15.04 \pm 0.79 \text { years }\end{array}$ & $\begin{array}{l}80 \% \text { study compliance } \\
\text { PA and Ca considered } \\
\text { United States }\end{array}$ & $\begin{array}{l}2 \text { semesters } \\
\text { EX: } 40 \text { min PA } 4 \text { times per week } \\
\text { ( } 3 \text { aerobic \& } 1 \text { strength) }+500 \mathrm{mg} \\
\text { Ca/D } \\
\text { CO: } 76 \% \text { enrolled in regular PE } \\
83 \% \text { intervention compliance }\end{array}$ & $\begin{array}{l}\text { WB BMC, BMD } \\
\text { LS BMC, BMD } \\
\text { FN BMC, BMD } \\
\text { PF BMC, BMD } \\
\text { FM } \\
\text { LM }\end{array}$ & $\begin{array}{l}\text { NS }(P \text { value not reported }) \\
\text { NS }(P \text { value not reported }) \\
\text { NS }(P \text { value not reported }) \\
\text { NS }(P \text { value not reported }) \\
\text { NS, } P=0.5 \\
\text { NS, } P=0.3\end{array}$ & $\begin{array}{l}\text { Non-randomised } \\
\text { Maturity not reported } \\
\text { APHV not reported }\end{array}$ & 17 \\
\hline
\end{tabular}




\begin{tabular}{|c|c|c|c|c|c|c|c|}
\hline $\begin{array}{l}\text { Linden, et al. } \\
2006 \text { (17) }\end{array}$ & $\begin{array}{l}\text { Girls } \\
\text { Ethnicity not reported } \\
\text { EX: } 49 \text { CO: } 50 \\
7.6 \pm 0.6 \text { years }\end{array}$ & $\begin{array}{l}90 \% \text { study compliance } \\
\text { PA considered } \\
\text { Tanner to assess } \\
\text { maturity } \\
\text { Sweden }\end{array}$ & $\begin{array}{l}2 \text { years } \\
\text { EX: } 5 \text { times per week } \\
40 \text { min: general PE } \\
\text { Additional to PE } \\
\text { CO: } 60 \text { min per week general PE } \\
91 \% \text { intervention compliance }\end{array}$ & $\begin{array}{l}\text { WB BMC } \\
\text { WB aBMD } \\
\text { LS BMC } \\
\text { LS aBMD } \\
\text { L3 BMC } \\
\text { L3 aBMD } \\
\text { L3 vBMD } \\
\text { FN BMC, aBMD } \\
\text { FM } \\
\text { LM }\end{array}$ & $\begin{array}{l}\text { NS, } P=0.1 \\
+1.5 \%, P=0.006 \\
+7 \%, P=0.007 \\
+1.6 \%, P=0.02 \\
+8.6 \%, P<0.0001 \\
+1.6 \%, P=0.006 \\
\text { NS, } P=0.5 \\
\text { NS, } P>0.5 \\
+9.5 \%, P<0.001 \\
+3.8 \%, P=0.01\end{array}$ & $\begin{array}{l}\text { Non-randomized study. } \\
\text { Calcium not reported } \\
\text { APHV not reported } \\
\text { GRF not reported }\end{array}$ & 17 \\
\hline $\begin{array}{l}\text { MacKelvie, et } \\
\text { al. } 2004 \text { (25) }\end{array}$ & $\begin{array}{l}\text { Boys } \\
\text { Caucasian, Asian } \\
\text { EX: } 31 \text { CO: } 33 \\
\text { Ex: } 10.2 \pm 0.5 \text { years; } \\
\text { CO: } 10.7 \pm 0.7 \text { years }\end{array}$ & $\begin{array}{l}\text { Schools randomised } \\
33 \% \text { study compliance } \\
\text { Tanner to assess } \\
\text { maturity } \\
\text { Canada }\end{array}$ & $\begin{array}{l}20 \text { months } \\
\text { EX: } 3 \text { times per week } \\
\text { 10-12 min jumping activities } \\
\text { (50-100 jumps) } \\
\text { Additional to PE } \\
\text { CO: Regular PE } \\
\text { GRF }=3.5-5 \text { times body weight } \\
\text { 99-100\% intervention compliance }\end{array}$ & $\begin{array}{l}\text { LS BMC } \\
\text { WB BMC } \\
\text { FN BMC } \\
\text { FN BA } \\
\text { PF BMC } \\
\text { FM } \\
\text { LM }\end{array}$ & $\begin{array}{l}\text { NS }(P \text { value not reported }) \\
\text { NS }(P \text { value not reported }) \\
+4.5 \%, P<0.01 \\
\text { NS, } P=0.07 \\
\text { NS }(P \text { value not reported }) \\
\text { NS }(P \text { value not reported }) \\
+4.2 \%, P<0.05\end{array}$ & $\begin{array}{l}\text { Participants not randomised } \\
\text { Study compliance } \\
\text { PA and Ca not reported } \\
\text { APHV not reported }\end{array}$ & 17 \\
\hline $\begin{array}{l}\text { McKay, et al. } \\
2000 \text { (31) }\end{array}$ & $\begin{array}{l}\text { Boys and girls } \\
\text { White, Asian } \\
\text { EX: } 63 \text { CO: } 81 \\
6.9-10.2 \text { years }\end{array}$ & $\begin{array}{l}\text { Schools randomised } \\
87 \% \text { study compliance } \\
\text { PA and Ca considered } \\
\text { Tanner to assess } \\
\text { Maturity } \\
\text { Canada }\end{array}$ & $\begin{array}{l}8 \text { months } \\
\text { EX: } 3 \text { times per week (twice into } \\
\text { PE) } \\
\text { 10-30 min: } 10 \text { tuck jumps }+ \\
\text { jumping/hopping (10min } \\
\text { minimum) }+ \text { circuit training } \\
\text { CO: Regular PE }\end{array}$ & $\begin{array}{l}\text { FM } \\
\text { LM } \\
\text { WB aBMD } \\
\text { PF aBMD } \\
\text { FN aBMD } \\
\text { TR aBMD } \\
\text { TR aBMD }\end{array}$ & $\begin{array}{l}\text { NS }(P \text { value not reported }) \\
\text { NS }(P \text { value not reported }) \\
\text { NS }(P \text { value not reported }) \\
\text { NS }(P \text { value not reported }) \\
\text { NS }(P \text { value not reported }) \\
\text { NS }(P \text { value not reported }) \\
+1.2 \%, P<0.05\end{array}$ & $\begin{array}{l}\text { Participants not randomised } \\
\text { Intervention compliance not } \\
\text { reported } \\
\text { APHV not reported } \\
\text { GRF not reported }\end{array}$ & 17 \\
\hline $\begin{array}{l}\text { MacKelvie, et } \\
\text { al. } 2003 \text { (23) }\end{array}$ & $\begin{array}{l}\text { Girls } \\
\text { Caucasian, Asian } \\
\text { EX: } 32 \text { CO: } 43 \\
\text { EX: } 9.9 \pm 0.6 \text { years } \\
\text { CO: } 10.3 \pm 0.4 \text { years }\end{array}$ & $\begin{array}{l}\text { Schools randomised } \\
42 \% \text { study compliance } \\
\text { Tanner to assess } \\
\text { maturity } \\
\text { Canada }\end{array}$ & $\begin{array}{l}20 \text { months } \\
\text { EX: } 3 \text { times per week } \\
10-12 \text { min: jumping activities } \\
\text { (50-100 jumps) } \\
\text { Additional to PE } \\
\text { CO: Regular PE } \\
\text { GRF }=3.5-5 \text { times body weight } \\
36 \% \text { intervention compliance }\end{array}$ & $\begin{array}{l}\text { LS BMC } \\
\text { WB BMC } \\
\text { FN BMC } \\
\text { PF BMC, BA } \\
\text { TR BMC, BA } \\
\text { FM } \\
\text { LM }\end{array}$ & $\begin{array}{l}+3.7 \%, P<0.05 \\
\text { NS }(P \text { value not reported }) \\
+4.6 \%, P<0.05 \\
\text { NS }(P \text { value not reported }) \\
\text { NS }(P \text { value not reported }) \\
\text { NS }(P \text { value not reported }) \\
\text { NS }(P \text { value not reported })\end{array}$ & $\begin{array}{l}\text { Participants not randomised } \\
\text { Low study and intervention } \\
\text { compliance } \\
\text { APHV not reported } \\
\text { PA and Ca not reported }\end{array}$ & 16 \\
\hline $\begin{array}{l}\text { Linden } 2007 \\
\text { (18) }\end{array}$ & $\begin{array}{l}\text { Boys } \\
\text { Caucasian } \\
\text { EX: } 81 \text { CO: } 57 \\
\text { EX: } 7.8 \pm 0.6 \text { years } \\
\text { CO: } 8 \pm 0.6 \text { years }\end{array}$ & $\begin{array}{l}90 \% \text { study compliance } \\
\text { PA considered } \\
\text { Tanner to assess } \\
\text { maturity } \\
\text { Sweden }\end{array}$ & $\begin{array}{l}1 \text { year } \\
\text { EX: } 5 \text { times per week } \\
40 \text { min: general PE } \\
\text { Additional to PE } \\
\text { CO: } 60 \text { min per week general PE } \\
91 \% \text { intervention compliance }\end{array}$ & $\begin{array}{l}\text { L3 BMC } \\
\text { L3 aBMD } \\
\text { L3 vBMD } \\
\text { WB BMC } \\
\text { WB aBMD } \\
\text { FN BMC } \\
\text { FN aBMD } \\
\text { FN vBMD } \\
\text { FM } \\
\text { LM }\end{array}$ & $\begin{array}{l}+6.1 \%, P<0.001 \\
+2.1 \%, P=0.01 \\
\text { NS, } P=0.8 \\
\text { NS, } P=0.6 \\
\text { NS, } P=0.2 \\
\text { NS, } P=0.2 \\
\text { NS, } P=0.9 \\
\text { NS, } P=0.6 \\
\text { NS, } P=0,1 \\
\text { NS, } P=0.4\end{array}$ & $\begin{array}{l}\text { Non-randomised } \\
\text { GRF not reported } \\
\text { Calcium not reported } \\
\text { APHV not reported }\end{array}$ & 16 \\
\hline
\end{tabular}




\begin{tabular}{|c|c|c|c|c|c|c|c|}
\hline $\begin{array}{l}\text { Van } \\
\text { Langendonck, } \\
\text { et al. } 2003 \text { (47) }\end{array}$ & $\begin{array}{l}\text { Twin girls } \\
\text { Ethnicity not reported } \\
\text { EX: } 21 \text { CO: } 21 \\
8+7 \pm 0.7 \text { years }\end{array}$ & $\begin{array}{l}\text { PA considered } \\
\text { Bone age and Tanner } \\
\text { considered } \\
\text { Study compliance not } \\
\text { reported } \\
\text { Belgium }\end{array}$ & $\begin{array}{l}9 \text { months } \\
\text { EX: } 3 \text { times per week } \\
10 \text { min skipping, hopping, jumping } \\
\text { from a box \& non-impact: moving } \\
\text { in a push-up and crab position } \\
\text { Additional to PE } \\
\text { CO: Not reported } \\
91 \% \text { intervention compliance }\end{array}$ & $\begin{array}{l}\text { FN BMC } \\
\text { FN aBMD } \\
\text { PF BMC } \\
\text { PF aBMD } \\
\text { FM } \\
\text { LM } \\
\text { \%BF }\end{array}$ & $\begin{array}{l}+1.3 \%, P<0.01 \\
+1.6 \%, P<0.01 \\
+2.4 \%, P<0.01 \\
+1.4 \% P<0.01 \\
-3.8 \%, P<0.01 \\
+0.7 \%, P<0.01 \\
-2.1 \%, P<0.001\end{array}$ & $\begin{array}{l}\text { Calcium not reported } \\
\text { Study compliance not } \\
\text { reported } \\
\text { GRF not reported } \\
\text { Control PA not reported } \\
\text { Calcium not reported }\end{array}$ & 16 \\
\hline $\begin{array}{l}\text { Morris, et al. } \\
1997 \text { (35) }\end{array}$ & $\begin{array}{l}\text { Girls } \\
\text { Ethnicity not reported } \\
\text { EX: } 38 \mathrm{CO}: 33 \\
9.5 \pm 0.9 \text { years }\end{array}$ & $\begin{array}{l}\text { Groups decided by } \\
\text { teachers. Matched by } \\
\text { ethnicity (not given) } \\
97 \% \text { study compliance } \\
\text { PA and Ca considered } \\
\text { Tanner to assess } \\
\text { maturity } \\
\text { Australia }\end{array}$ & $\begin{array}{l}10 \text { months } \\
\text { EX: } 3 \text { times per week } \\
30 \text { min MVPA + weight-bearing } \\
\text { training } \\
\text { Additional to PE } \\
\text { CO: not to change PA patterns } \\
92 \% \text { intervention compliance }\end{array}$ & $\begin{array}{l}\text { WB BMC } \\
\text { WB aBMD } \\
\text { LS BMC } \\
\text { LS aBMD } \\
\text { LS BMAD } \\
\text { FN BMC } \\
\text { FN aBMD } \\
\text { PF BMC } \\
\text { PF aBMD } \\
\text { FM } \\
\text { LM }\end{array}$ & $\begin{array}{l}+5.5 \%, P=0.001 \\
+2.3 \%, P=0.001 \\
+5.5 \%, P=0.05 \\
+3.6 \%, P=0.04 \\
+2.9 \%, P=0.05 \\
+4.5 \%, P=0.001 \\
+10.3 \%, P=0.01 \\
+8.3 \%, P=0.01 \\
+3.2 \%, P=0.001 \\
-6.2 \%, P=0.04 \\
+3.4 \%, P=0.01\end{array}$ & $\begin{array}{l}\text { Non-randomised } \\
\text { GRF not reported } \\
\text { APHV not reported }\end{array}$ & 16 \\
\hline $\begin{array}{l}\text { McKay, et al. } \\
2005 \text { (30) }\end{array}$ & $\begin{array}{l}\text { Boys and girls } \\
\text { Caucasian and Asian } \\
\text { EX: } 51 \text { CO: } 75 \\
10.2 \pm 0.43 \text { years }\end{array}$ & $\begin{array}{l}100 \% \text { study compliance } \\
\text { CO from previous study } \\
\text { PA and Ca considered } \\
\text { Tanner to assess } \\
\text { maturity } \\
\text { Canada }\end{array}$ & $\begin{array}{l}8 \text { months } \\
\text { EX: } 5 \text { times per week } \\
30 \text { counter movement jumps ( } 3 \\
\text { times per day) + regular PE } \\
\text { CO: Regular PE } \\
\text { GRF }=5 \text { times body weight } \\
60 \% \text { intervention compliance }\end{array}$ & $\begin{array}{l}\text { TR BMC } \\
\text { PF BMC } \\
\text { TR BA } \\
\text { PF BA } \\
\text { FM } \\
\text { LM }\end{array}$ & $\begin{array}{l}+2.7 \%, P=0.02 \\
+2.0 \%, P<0.02 \\
+2.0 \%, P=0.07 \\
+1.3 \%, P=0.07 \\
\text { NS, } P=0.9 \\
\text { NS, } P=0.2\end{array}$ & $\begin{array}{l}\text { WB BMC greater in control } \\
\text { than intervention group } \\
(\mathrm{p}<0.05) \\
\text { EX had higher PA load than } \\
\text { CO during baseline } \\
\text { Non-randomised } \\
\text { Low intervention } \\
\text { compliance }\end{array}$ & 15 \\
\hline $\begin{array}{l}\text { Casazza, et al. } \\
2012 \text { (5) }\end{array}$ & $\begin{array}{l}\text { Boys and girls } \\
\text { European American, } \\
\text { African American, } \\
\text { Hispanic American } \\
\text { EX: } 10 \mathrm{CO}: 10 \\
4.8 \pm 0.2 \text { years }\end{array}$ & $\begin{array}{l}\text { Pilot study } \\
\text { United States }\end{array}$ & $\begin{array}{l}10 \text { weeks } \\
\text { EX: } 3 \text { times per week } \\
30 \text { min: } 5 \text { warm-up - } 20 \text { jump } \\
\text { activities - } 5 \text { cool down } \\
\text { Additional to PE } \\
\text { CO: Not reported } \\
>90 \% \text { intervention compliance }\end{array}$ & $\begin{array}{l}\text { WB BMC } \\
\text { FM } \\
\text { LM } \\
\text { \%BF }\end{array}$ & $\begin{array}{l}\text { NS, } P=0.5 \\
\text { NS, } P=0.2 \\
\text { NS, } P=0.2 \\
\text { NS, } P=0.3\end{array}$ & $\begin{array}{l}\text { Non-randomised } \\
\text { GRF not reported } \\
\text { PA and Ca not reported } \\
\text { Maturity status not reported } \\
\text { Low sample size }\end{array}$ & 14 \\
\hline $\begin{array}{l}\text { Gutin, et al. } \\
2008 \text { (12) }\end{array}$ & $\begin{array}{l}\text { Boys and girls } \\
\text { Black, White } \\
\text { EX: } 148 \text { (42 reached } \\
40 \% \text { attendance) } \\
\text { CO: } 168 \\
8.5 \pm 0.6 \text { years }\end{array}$ & $\begin{array}{l}\text { Randomised } \\
44 \% \text { study compliance } \\
\text { United States }\end{array}$ & $\begin{array}{l}3 \text { years } \\
\text { EX: } 5 \text { times per week } \\
80 \text { min: } 40 \text { min MVPA - } 40 \text { min } \\
\text { sport skills, stretching } \\
\text { After-school intervention } \\
29 \% \text { intervention compliance }\end{array}$ & $\begin{array}{l}\text { WB BMD } \\
\text { FM } \\
\text { FFST } \\
\% \text { BF }\end{array}$ & $\begin{array}{l}+3.6 \%, P<0.01 \\
\text { NS (p value not reported) } \\
+5.6 \%, P<0.01 \\
-7.7 \%, P<0.05\end{array}$ & $\begin{array}{l}\text { GRF not reported } \\
\text { PA and Ca not reported } \\
\text { Maturity status not reported } \\
\text { Low study and intervention } \\
\text { compliance }\end{array}$ & 13 \\
\hline
\end{tabular}




\begin{tabular}{|c|c|c|c|c|c|c|c|}
\hline $\begin{array}{l}\text { Barbeau, et al. } \\
2007 \text { (3) }\end{array}$ & $\begin{array}{l}\text { Girls } \\
\text { Black } \\
\text { EX: } n=118 \text { CO: } n=83 \\
8-12 \text { years }\end{array}$ & $\begin{array}{l}\text { Randomised } \\
54 \% \text { study compliance } \\
\text { PA considered } \\
\text { Tanner to assess } \\
\text { maturity } \\
\text { United States }\end{array}$ & $\begin{array}{l}10 \text { months } \\
\text { EX: } 5 \text { times per week } \\
80 \text { min: } 25 \text { min skills development, } \\
35 \text { min MVPA, } 20 \text { min stretching } \\
\text { After-school intervention } \\
\text { CO: no intervention } \\
54 \% \text { intervention compliance }\end{array}$ & $\begin{array}{l}\text { WB BMC } \\
\text { WB BMD } \\
\text { FM } \\
\text { FFST } \\
\text { \%BF } \\
\text { BMI }\end{array}$ & $\begin{array}{l}\text { NS, } P<0.0001 \\
1.1 \%, P<0.0001 \\
-9.3 \%, P=0.0003 \\
\text { NS, } P=0.1 \\
-4.6 \%, P<0.0001 \\
-2.9 \%, P=0.008\end{array}$ & $\begin{array}{l}\text { GRF not reported } \\
\text { Ca not reported } \\
\text { Low study and intervention } \\
\text { compliance } \\
\text { APHV not reported }\end{array}$ & 13 \\
\hline $\begin{array}{l}\text { McWhannel, et } \\
\text { al. } 2008 \text { (32) }\end{array}$ & $\begin{array}{l}\text { Boys and girls } \\
\text { White, Black, Asian } \\
\text { EX:16 Lifestyle: } 15 \\
\text { CO:30 } \\
11 \pm 0.3 \text { years }\end{array}$ & $\begin{array}{l}75 \% \text { study compliance } \\
\text { Tanner to assess } \\
\text { Maturity } \\
\text { United Kingdom }\end{array}$ & $\begin{array}{l}9 \text { weeks } \\
\text { EX: } 2 \text { times per week } \\
1 \text { h high-impact }(+70 \% \text { HRmax) } \\
\text { Lifestyle: mail with tasks weekly } \\
\text { After-school intervention } \\
\text { CO: no intervention } \\
\text { 99-100\% intervention compliance }\end{array}$ & $\begin{array}{l}\text { WB BMC } \\
\text { WB BMD } \\
\text { FM } \\
\text { LM } \\
\% \text { BF } \\
\text { BMI }\end{array}$ & $\begin{array}{l}+5.8 \%, P<0.05 \\
+1.5 \%, P<0.05 \\
\text { NS }(P \text { value not reported }) \\
\text { NS ( } P \text { value not reported }) \\
\text { NS ( } P \text { value not reported }) \\
\text { NS ( } P \text { value not reported })\end{array}$ & $\begin{array}{l}\text { Non-randomised } \\
\text { GRF not reported } \\
\text { PA and Ca not reported } \\
\text { Low sample size } \\
\text { Short intervention period }\end{array}$ & 12 \\
\hline
\end{tabular}

Results are presented as the percentage difference in change between intervention and control groups.

EX, experimental group; CO, control group, PA, physical activity; Ca, calcium; D, vitamin D; PE, physical education; GRF, ground reaction forces; DXA, dual energy x-ray absorptiometry; BMC, bone mineral content; BMD, bone mineral density; BA, bone area; LS, lumbar spine; FN, femoral neck; WB, whole body; TR, trochanter; PF, proximal femur; LM, lean mass; FM, FFST, fat free soft tissue; fat mass; \% BF, percent body fat; NS, not significant; APHV, age of peak height velocity; MVPA, moderate to vigorous physical activity; d, day; BMI, body mass index, HRmax, maximum heart rate. 


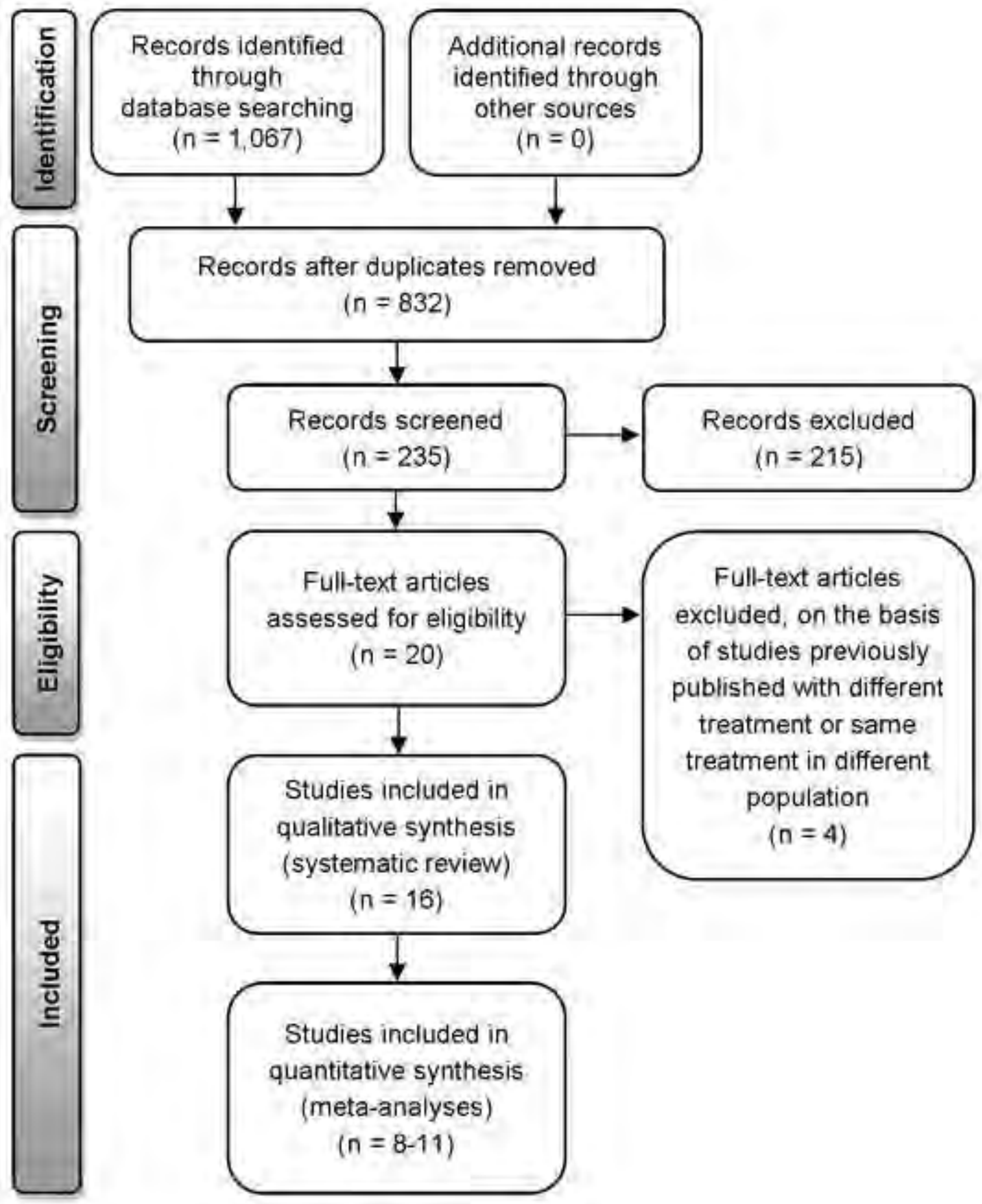

Additional records

identified through$$
\text { (n) }
$$$$
(n=0)
$$

$$
(n=215)
$$

Full-text articles of studies previousiy ublished with different treatment or same treatment in different population

$$
(n=4)
$$

Studies included in quantitative synthesis (meta-analyses)

$$
(n=8-11)
$$


Review: Effect of exercise on whole body bone mass

Comparison: Exercise vs. control

Outcome: Change in whole body BMC (g)

Study N

Weeks et al. (2008)

Linden et al. (2006)

MacKelvie et al. (2004)

Mackelvie et al. (2003)

Linden et al. (2007)

Van Langendonck et al. (2003)

Morris et al. (1997)

Overall effect
81

99

64

75

138

42

71

.

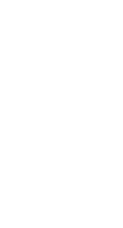

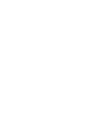

SMD $(95 \% \mathrm{CI})$

$1.132(0.662,1.603)$

$0.304(-0.092,0.700)$

$0.430(-0.066,0.926)$

$0.336(-0.125,0.797)$

$0.130(-0.209,0.469)$

$-0.162(-0.768,0.444)$

$1.210(0.702,1.719)$

$0.483(0.132,0.833)$

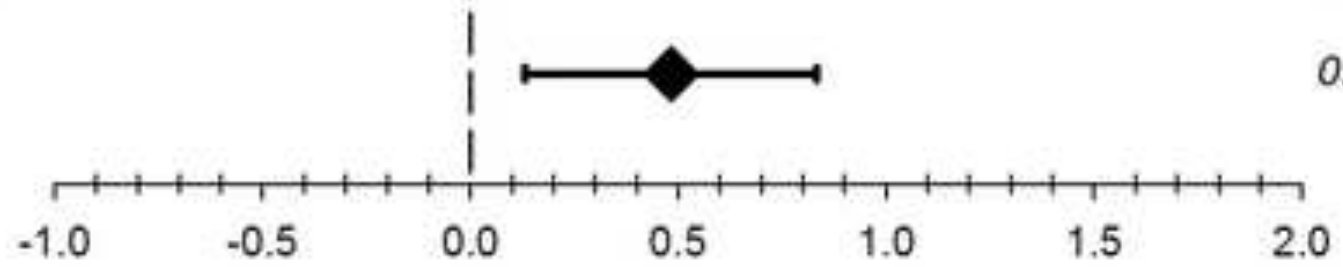

Favours Control Favours Exercise 

A Review: Effect of exercise on femoral neck bone mass
Comparison: Exercise vs, control
Outcome: Change in femoral neck BMC (B)

Study

Weeks et al. (2008)

Linden et af. (2006)

MacKelvie et al. (2004)

Mackelvie et al. (2003)

Linden et al. (2007)

Van Langendonck et of. (2003)

Morris et al. (1997)

Overall effect

\section{N}

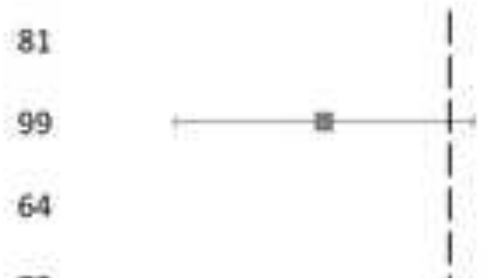

75

138

42

71

1

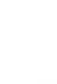

SMD $(95 \% \mathrm{CI})$

$0.750(0.281,1.219)$

$-0.333(-0.733,0.066)$

$0.846(0.314,1.378)$

$0.500(0.030,0.970)$

$0.190(-0.150,0.531)$

$0.214(-0.394,0.823)$

$-0.011(-0.477,0.456)$

$0.292(-0.022,0.607)$

B Review: Effect of exercise on lumbar spine bone mass

Comparison: Exercisevs, control

Outcome: Change in lumbar spine BMC (8)

Study

Weeks et al. (2008)

Linden et ol. (2006)

Mackelvie et of. (2004)

Mackelvie et al, (2003)

Van Langendonck et al. (2003)

Morris et al. (1997)

Overail effect
N

81

99

64

75

42

71

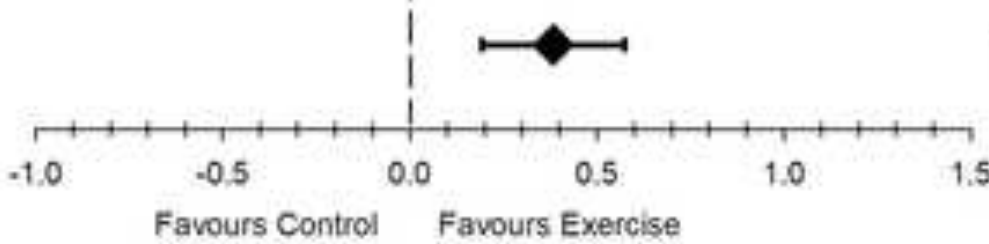

Favours Control Favours Exercise
SMD ( $95 \% \mathrm{CI})$

$0.234(-0.204,0.672)$

$0.510(0.110,0.911)$

$0.258(-0.234,0.751)$

$0.559(0.093,1.026)$

$0.221(-0.386,0.828)$

$0.418(-0.054,0.890)$

$0.384(0.193,0.575)$ 
Click here to download high resolution image

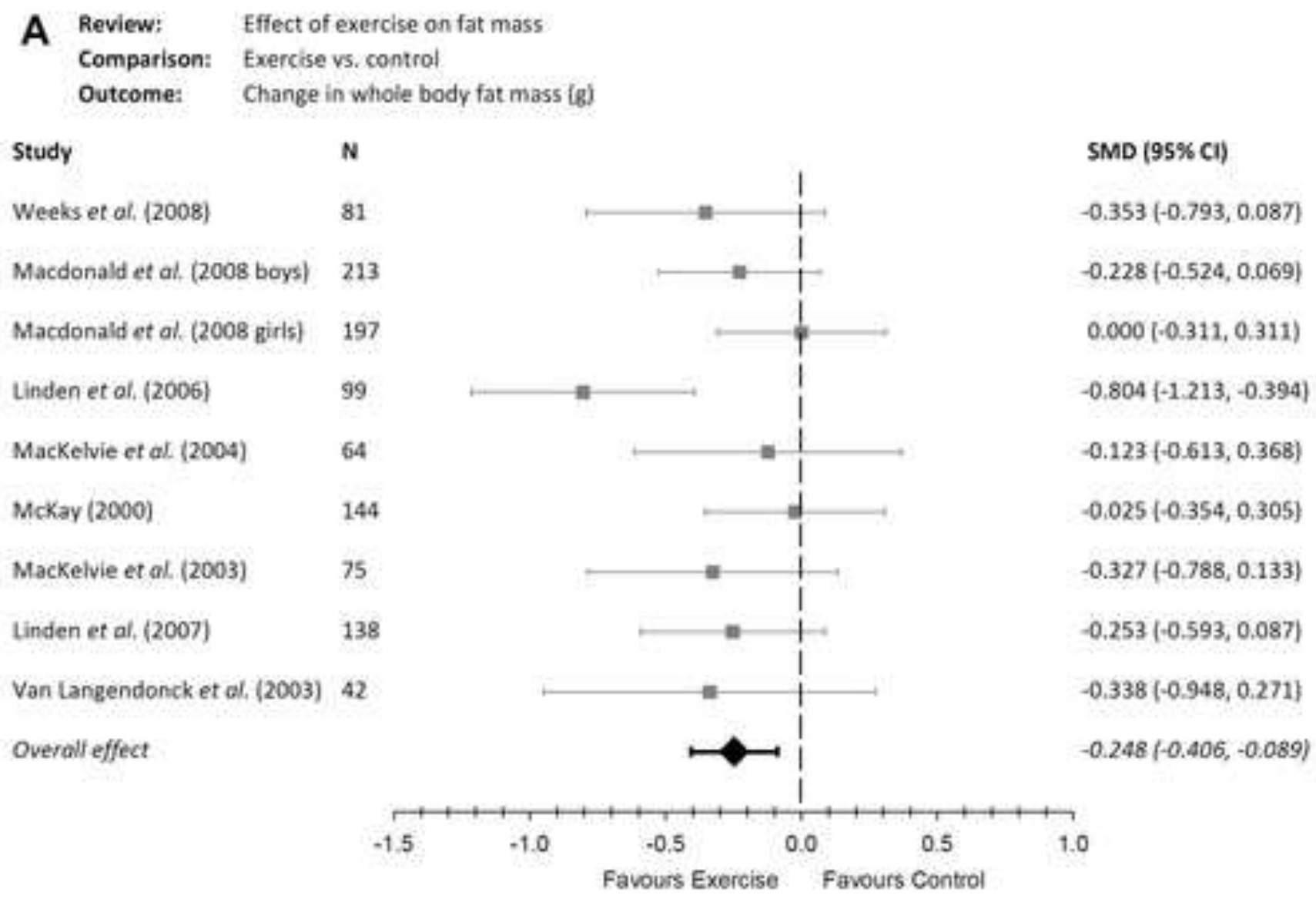

B Review: Effect of exercise on lean mass

Comparison: Exercise vs, control

Outcome: Change in whole body lean mass $(\mathrm{g})$

\section{Study}

Weeks et al, (2008)

Macdonald et al. (2008 boys)

Macdonald et al. (2008 gitts).

Linden et al. (2006)

Mackelvie et al. (2004)

McKay (2000)

MacKelvie et of (2003)

Unden et of. (2007)

Van Langendonck et ol. (2003)

Morris et al. (1997)

Overall effect
N

B1

213

197

99

64

144

75

138

42

71

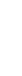

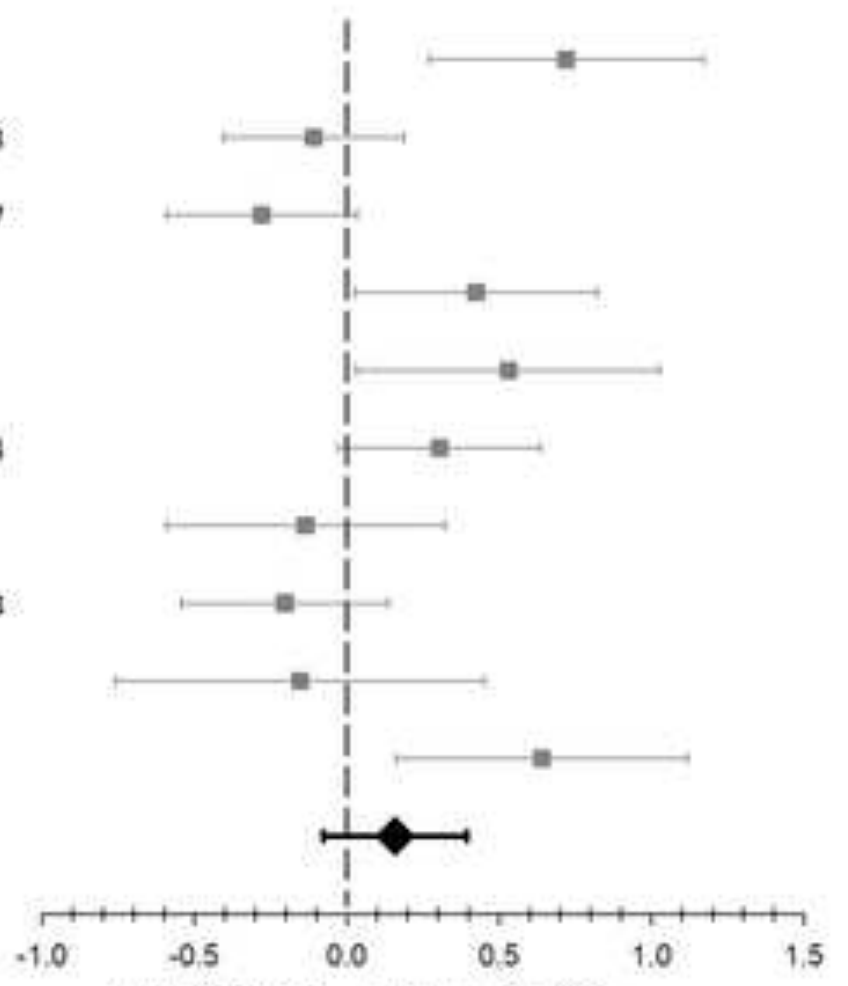

Favours Control Favours Exercise
SMD $(95 \% \mathrm{C})$

$0.720(0.269,1.170)$

$-0.108(-0.403,0.188)$

$-0.280(-0.592,0.0 .33)$

$0.425(0.026,0.823)$

$0.530(0.031,1.029)$

$0.304(-0.027,0.635)$

$-0.135(-0.593,0.323\}$

$-0.203(-0.543,0.137\}$

$-0.153(-0.759,0.453)$

$0.641(0.162,1.119)$

$0.159(-0.076,0.394)$ 